University of California, Hastings College of the Law

UC Hastings Scholarship Repository

Faculty Scholarship

$8-2020$

\title{
When Does A Minor's Legal Competence To Make Health Care Decisions Matter?
}

Lois A. Weithorn

University of California, Hastings College of the Law, weithorn@uchastings.edu

Follow this and additional works at: https://repository.uchastings.edu/faculty_scholarship

\section{Recommended Citation}

Lois A. Weithorn, When Does A Minor's Legal Competence To Make Health Care Decisions Matter?, 146

Pediatrics s25 (2020).

Available at: https://repository.uchastings.edu/faculty_scholarship/1782

This Article is brought to you for free and open access by UC Hastings Scholarship Repository. It has been accepted for inclusion in Faculty Scholarship by an authorized administrator of UC Hastings Scholarship Repository. For more information, please contact wangangela@uchastings.edu. 


\section{When Does A Minor's Legal Competence To Make Health Care Decisions Matter?}

Lois A. Weithorn, PhD, JD

In this article, I examine the role of minors' competence for medical decision-making in modern American law. The doctrine of parental consent remains the default legal and bioethical framework for health care decisions on behalf of children, complemented by a complex array of exceptions. Some of those exceptions vest decisional authority in the minors themselves. Yet, in American law, judgments of minors' competence do not typically trigger shifts in decision-making authority from adults to minors. Rather, minors' decisional capacity becomes relevant only after legislatures or courts determine that the default of parental discretion does not achieve important policy goals or protect implicated constitutional rights in a particular health care context and that those goals can best be achieved or rights best protected by authorizing capable minors to choose for themselves. It is at that point that psychological and neuroscientific evidence plays an important role in informing the legal inquiry as to whether minors whose health is at issue are legally competent to decide.

University of California, Hastings College of the Law, San Francisco, California

Dr Weithorn is the sole author of and contributor to this article and approved the final manuscript as submitted

DOI: https://doi.org/10.1542/peds.2020-0818G

Accepted for publication May 18, 2020

Address correspondence to Lois A. Weithorn, PhD, JD, University of California, Hastings College of the Law, 200 McAllister St, San Francisco, CA 94102. E-mail: weithorn@uchastings.edu

PEDIATRICS (ISSN Numbers: Print, 0031-4005; Online, 1098-4275).

Copyright @ 2020 by the American Academy of Pediatrics

FINANCIAL DISCLOSURE: The author has indicated she has no financial relationships relevant to this article to disclose.

FUNDING: No external funding.

POTENTIAL CONFLICT OF INTEREST: The author has indicated she has no potential conflicts of interest to disclose. 
Questions about minors' capacities to make personal health care decisions emerged in law and scholarship in the 1970s and 1980s, ${ }^{1,2}$ reflecting a broader rethinking in society about the legal status of children. ${ }^{3}$ In certain groundbreaking cases involving mental health and reproductive health, ${ }^{4-6}$ courts held state laws permitting unchecked parental discretion to be unconstitutional. ${ }^{7}$ If sole parental discretion would not govern in these contexts, policy makers and others wondered: would minors be competent to decide for themselves? These trends occurred contemporaneously with the evolution of the doctrine of informed consent beyond its tort law origins, ${ }^{8}$ highlighting its bioethical grounding in principles of autonomy and selfdetermination. ${ }^{9}$

Today, the doctrine of parental consent remains the default legal and bioethical framework for health care decisions for children. Yet, the law reveals a complex array of exceptions to the doctrine. ${ }^{10}$ Each exception provides for a decision-making mechanism to supplement or, in some cases, replace parental discretion. In some instances, that alternative mechanism supplants parental decisions with those of the court. In other instances, however, these mechanisms authorize minors to decide for themselves.

Every now and then, however, a case comes to public attention that forces us to think long and hard about the contours of exceptions to the doctrine of parental consent. Such is the case of Dennis Lindberg. ${ }^{11}$ In 2007, a county court judge in the state of Washington allowed 14-year-old Dennis to refuse lifesaving transfusions on religious grounds, finding the youth mature enough to make his own decision. ${ }^{12}$ With conventional treatment, Dennis had a good prognosis for a disease-free future. He died, however, shortly after the court allowed him to refuse treatment. Although a broad "mature minor" rule does not operate in most states, the possibility of future cases like that of Dennis Lindberg underscores the importance of examining when the competence of minors to make treatment decisions matters in the law.

In American law, judgments of minors' competence typically are not the sole or primary basis for a shift in decision-making authority from adults. Minors' decisional competence is rarely the star of the show. When it is given a role to play, it is usually as a supporting player. Typically, minors' decisional capacities become relevant only after courts or legislatures conclude that the default of parental discretion does not achieve important policy goals or protect implicated constitutional rights. Often the state steps in and assumes decisionmaking authority from the parents. Whether, instead, minors are legally authorized to decide depends on a range of policy, constitutional, and practical considerations. Minors may be legally permitted to decide about one type of treatment, but not another. Or they may be permitted to consent, but not refuse, a particular intervention. These discrepancies do not typically demonstrate inconsistent thinking about minors' capacities to make treatment decisions. They reflect the policy goals underlying authority rules for each type of health care decision.

Clinical and ethical considerations, in contrast to legal rules, strongly support involving children in health care decisions. ${ }^{13,14}$ As I have written elsewhere, ${ }^{15}$ there exist a myriad of reasons to promote children's involvement in personal health care decisions as partners with the legally authorized decision-makers and health care team. ${ }^{14}$ Independent of legal rules, minors' interests in determining what happens to their bodies and futures deserve some weight. Bioethical analyses often accord the interests and preferences of minors' increasing weight as minors mature and their health care decision-making capacities approach, or are comparable with, those of adults. In this article, however, I confine my remarks to identifying the rules governing legal authority for health care decisions for minors.

\section{THE DOCTRINE OF PARENTAL CONSENT}

Parental discretion is the starting point for analyses of decisional authority regarding children or adolescents, ${ }^{4}$ and it is typically the end point as well. The doctrine of parental consent, which authorizes parents to make most health care decisions for their minor children, is one expression of the broad, multifaceted, and constitutionally protected authority of parents to make decisions affecting the welfare of their minor children. ${ }^{16}$

There are at least 4 inextricably interwoven rationales for this parental discretion in child-rearing. First, the family, as a unit, has a special place in American society. It is uniquely suited to perform the social roles of procreation, nurturance, support, and socialization of children. ${ }^{17}$ Parental discretion also protects against governmental overreaching and promotes pluralism and diversity, which reinvigorates our democracy. Thus, protection for parental decisional authority over their minor children achieves a myriad of social goals. ${ }^{10}$

Second, parental discretion is an essential companion to the legally enforceable duties of care and protection of their minor children that parents assume. Providing parents with some measure of freedom (within limits) in fulfilling these weighty responsibilities is thought to strengthen parental commitment and investment. ${ }^{17}$

Third, most children have not yet achieved adult levels of maturity in a range of areas of functioning. They depend on adults to meet their essential needs. ${ }^{18}$ Although the age at 
which children typically reach milestones characterizing adult levels of functioning varies across individuals, and depending on the tasks in question, most children require and rely on adult care, protection, and guidance. ${ }^{18}$ The law treats the generalization of minors' incapacity as a legal presumption ${ }^{19,20}$ irrespective of its accuracy in individual cases. The existence of a bright-line rule facilitates day to day relations among parents, children, the state, and third parties.

Fourth, if minors are generally not capable, parents are the logical first choice to serve as proxy decisionmakers. ${ }^{4}$ Parents are presumed to be motivated to make and capable of making decisions in their children's best interests. ${ }^{21}$ We further presume that there exists an "identity of interests" between parent and child, that is, that the interests of parents and children typically align and are not in conflict. ${ }^{3,22,23}$

Although these 4 justifications do not exhaust all of the rationales for the doctrine of parental consent, together they provide powerful support for the current status quo. They also reveal why policy makers are not overly concerned that the bright-line, agebased division between minority and majority often does not track minors' de facto or actual competence for particular legal purposes. Minors' actual capacities are not usually dispositive of their rights to decide.

\section{EXCEPTIONS TO THE DOCTRINE OF PARENTAL CONSENT}

A handful of exceptions to the doctrine of parental consent exist. Most, although not all, of these exceptions exist because legislatures and courts have determined that (1) the state's and/or child's interests outweigh those of the parents in a particular context or (2) barriers exist that prevent parents from acting in their children's interests in accessing needed health care. Minors may be authorized to decide independently if policy makers conclude it is the most effective way to achieve policy goals or protect implicated rights.

The law recognizes the state as a partner to parents in raising children. Government retains limited authority to intervene in parental decisions when it determines that doing so is necessary either to protect a child's well-being or to promote the general welfare. Thus, for example, statutes mandating childhood vaccinations before school entry seek to achieve the dual purposes of benefiting the vaccinated children and protecting the public from contagious diseases. ${ }^{24}$ Legislatures and courts have determined that these interests, in the context of this high benefit/low risk intervention, outweigh parental interests in exercising discretion.

The state also maintains oversight of parental decisions on a case by case basis. Civil and criminal medical neglect provisions create a floor below which parents' failures to provide for their children's health justifies state intervention. Generally, such intervention is conditioned on a judicial finding that a parent's failure to access certain treatment creates "a substantial risk that the child will suffer serious physical harm or illness." ${ }^{25}$ Child maltreatment statutes exist to vindicate the state's interest in furthering the well-being of the child whose care is at issue for that child's own sake and for the benefit of society at large. The state has a strong interest in fostering each child's transformation into a healthy and contributing adult member of society.

Some courts have considered minors interests apart from those of parents or the state. They have held that children have a "right to enjoy a full and healthy life" 26 through access to standard medical interventions that offer the opportunity to be free from the harmful effects of life-threatening and other serious diseases. ${ }^{27}$ Analyses of minors' interests in decisional autonomy have also influenced modern law, ${ }^{5,6}$ although minors' rights in these contexts are not generally coextensive with those of adults. Some of these interests have achieved constitutional status, such as the rights of minors to make choices regarding their reproductive health.,

There exist various treatment-specific exceptions that grant minors independent (or in the case of abortion, typically semi-independent) access to a range of interventions. State statutes, and occasionally case law, frequently provide minors with access to services related to contraception, prenatal care, abortion, outpatient mental health and substance abuse, sexually transmitted diseases, and sexual assault. The rationales for such exceptions include a complex mix of constitutional, policy, and practical factors that vary across the type of health care involved. Yet, there are many commonalities as well.

First, these treatments involve sensitive matters that minors are often hesitant to disclose to their parents. Whether minors' fears or apprehensions about discussing these matters with their parents are justified, parents cannot facilitate their minors' access to treatment if they are unaware of the problem. Furthermore, a parent-child conflict may exist if minors experience parental opposition to their treatment choice or reasonably fear negative repercussions after disclosure of that choice to parents. ${ }^{10}$

Second, with respect to most of these exceptions, there is a broad societal consensus and substantial scientific evidence as to the benefits to the minors and society of facilitating minors' access to these services. For example, there is widespread acceptance of, and strong scientific 
evidence for, the premise that preventing unwanted teenaged pregnancy through contraception is in the interest of sexually active minors and also advances a range of societal interests. ${ }^{10,28}$ Similar views exist regarding the other treatment categories listed above, with the possible exception of abortion, about which social attitudes remain divided.

Third, constitutional, policy, or other considerations elevate the importance of supporting the minors' decisional autonomy in some of these treatment contexts. Most of these exceptions are not propelled, in the first instance, by the goal of granting minors decision-making authority commensurate with their capacities. Yet, our knowledge about those capacities informs the question of whether granting minors decisional authority serves the identified policy goals. Once the default of sole parental consent has been determined inapt for policy or constitutional reasons, determinations of minors' competence move to center stage because competence is a precondition for legally valid consent.

The above analysis does not contain an exclusive list of situations in which the law might, and perhaps should, give weight or authority to minors' choices in health care, even over parental objection. As minors approach majority, courts may be increasingly willing to allow them to play a role in their own health in contentious cases. ${ }^{29}$ Furthermore, depending on the risk/benefit profile of an intervention and the prognosis with or without treatment, minors may be authorized to play a greater role in their own health care decisions. Yet, importantly, inquiries about competence tend to follow, rather than lead, other steps in legal determinations about who should have decisional authority in particular situations.
CAPACITY, COMPETENCE, MATURITY, AND THE MATURE MINOR DOCTRINE

Capacity and Competence Standards and Frameworks

The MacArthur Treatment Competence Study identified 4 standards of competence, one or more of which are often used in various health care decision-making contexts: (1) ability to communicate a choice, (2) ability to understand relevant information, (3) ability to reason about treatment options, and (4) ability to appreciate the situation and its likely consequences. ${ }^{30,31}$ In California, for example, the statutory definition of competence refers to "a person's ability to understand the nature and consequences of a decision and to make and communicate a decision, and includes...the ability to understand [the] significant benefits, risks, and alternatives [of a proposed treatment]." 32

Different standards and levels of capacity may be required in different situations, often depending on various features of the decisionmaking context, such as the risk/ benefit profile and the consequences of nontreatment. In some contexts, consents and refusals are treated differently. For example, in the United Kingdom, there exists an asymmetry in the ages at which minors are permitted to consent to, rather than refuse, treatment. This framework permits minors aged $<16$ who meet the test of competence announced in Gillick $v$ West Norfolk and Wisbech Area Health Authority ${ }^{33}$ to provide independent consent for treatment. But parents or the state can override their treatment refusals. Minors aged 16 and 17 are presumed capable of making their own health care decisions. But if they refuse a treatment that is determined necessary to preserve their lives or avoid serious harm, the minor's refusal may be overridden by their parents or the court. ${ }^{34}$ Although some have criticized this framework, the policies reflect a social consensus in favor of preserving good health, life, and survival to adulthood while respecting the minor's developing autonomy. This approach demonstrates the various roles minors' competence may play, depending on the social goals and values a government seeks to advance.

\section{Psychological Science and} Neuroscientific Research Relevant to Minors' Competence

In the 1970 s and early 1980s, relying on then-available developmental research, some scholars hypothesized that minors aged 14 or 15 might be able to satisfy legal standards of competence to consent. ${ }^{1,35}$ Our knowledge about minors' decisional capacities evolved in subsequent decades, as scientists observed that brain maturation continues into adulthood. ${ }^{36}$ Scientists learned that "psychosocial characteristics such as impulsivity, sensation seeking, future orientation, and susceptibility to peer pressure" undergo such continued development. ${ }^{37}$ By contrast, "the ability of a person to reason and consider alternative courses of action" (core skills for effective treatment decision-making) was "found to reach adult levels during the mid-teen years..."38

Psychological scientists, such as Laurence Steinberg and Grace Icenogle, have interpreted these differential findings, distinguishing between "cold" and "hot" cognition. "Cold cognition refers to mental processes (such as working memory or response inhibition) employed in situations calling for deliberation in the absence of high levels of emotion." ${ }^{38}$ Generally during circumstances characterized by cold cognition, adolescents display relatively unimpeded access to adultlike logical reasoning abilities, in that emotional arousal is lower and peer influence is minimized. 39 "Hot 
cognition involves mental processes in affectively charged situations where deliberation is unlikely or difficult." ${ }^{38}$ In these situations, factors such as impulse control and susceptibility to peer influence can interfere with an adolescent's use of his or her reasoning and analytic thinking skills. ${ }^{39}$ Some scientists have pointed to a "maturity gap," or differential, in the points in development at which individuals are most likely to demonstrate adult-like functioning on tasks invoking cold versus hot cognition. ${ }^{38}$ In contrast to decisions made in the context of criminal behavior or regarding use of alcohol or drugs, which are often influenced by peers, medical decisions typically occur in circumstances "where the presence of adult consultants and the absence of time pressure impose sufficient external control to minimize the dangers of impulsive decision making...."38 In light of the cumulative body of research, various groups of scientists have predicted that minors would be capable of making mature health care decisions by adolescence. Yet, whereas some predict that minors as young as 11 or 12 may manifest such capacities, ${ }^{40}$ others identify age 15 or $16 .^{38}$

Empirical research focused on treatment competence further informs these questions. ${ }^{41,42}$ Weithorn and Campbell's ${ }^{43} 1982$ study and investigations that followed the MacArthur Treatment Competence Study's work have incorporated assessment according to the legal standards of competence. $^{44-48}$ Whereas some research examined participants' responses to hypothetical medical vignettes in the laboratory, others evaluated the capacities of minors relative to their own decisions to participate in treatment or clinical research.

Those studies that have conducted criterion-relevant assessments,(ie, have tracked the applicable legal standards) and have compared minors with adults rather than to an abstract (and possibly) idealized benchmark have found no statistically significant differences between adolescents aged 14 and older and adults. ${ }^{43}$ Weithorn and Campbell ${ }^{43}$ studied minors aged 10 to $11,14,18$, and 21 . They did find statistically significant differences between the youngest group and the 3 older groups on most competence scales. The research of Hein et al, ${ }^{44-46}$ which included minors aged 12 and 13, suggests that even minors in those preadolescent and early adolescent age groups can demonstrate adultlike competence according to the MacArthur standards. A Canadian panel of experts charged with evaluating the literature for the purpose of making recommendations regarding the availability of medical aid in dying to mature minors has recently characterized the body of research as follows: "Together, these data point to the idea that cognitive foundations for mature decisions are generally in place by early adolescence (12 to 15 years of age)."

Yet not all health care decisions are the same. On the one hand, the cognitive and psychological demands of decision-making scenarios differ in, for example, the complexity of the disclosed information and the difficulty of deciding among options. Such variability could lead to observed differences among minors during the transitional ages of 12 to 15 years. Furthermore, the nature and consequences of particular health care decisions and the constellation of interests involved may lead policy makers to employ different standards of competence or different thresholds for determining when competence is achieved.

\section{The Mature Minor Doctrine}

The term "maturity" is sometimes used in place of, or in addition to, capacity or competence. The mature minor doctrine is a statutory or case law principle that allows minors authority to consent to or reject general medical treatment under certain circumstances. ${ }^{20,49-52}$ Only a minority of states have adopted any form of a mature minor rule, and those that have demonstrate substantial variation in the parameters of that rule. ${ }^{51}$ States initially adopted mature minor rules to eliminate legal liability of health care professionals treating minors in circumstances in which parents were unavailable or unwilling to consent. $^{50,51}$ In 1973, the late Professor Walter Wadlington observed that the cases to which the rule had been applied generally involved older minors (aged 15 and older), who were considered to be competent, and medical procedures that were neither major nor serious in nature. ${ }^{49}$ Today, the generic form of the doctrine has not been widely adopted. ${ }^{20,51}$ Yet it has sometimes been expanded to situations in which the treatment decision is both major and serious. ${ }^{29}$ This is the doctrine that Judge John Meyer relied on to allow Dennis Lindberg to refuse treatment. ${ }^{15}$

The meaning of the term "maturity" under these statutes and cases is not always clear. ${ }^{51,53}$ Some statutes and case law treat the term "maturity" as synonymous with competence. ${ }^{54-56}$ This approach to maturity was articulated, for example, by the Maine Supreme Court in In re Swan, when noting, "Capacity exists when the minor has the ability of the average person to understand and weigh the risks and benefits." ${ }^{56}$

Yet in some cases, judges have laid out 2 sets of standards: the more familiar treatment decision-making competence standard and a broader maturity standard that references a host of social, emotional, and psychological factors beyond such treatment competence. ${ }^{57,58}$ For example, the Tennessee Supreme Court in Cardwell $v$ Bechtol considered "the age, ability, experience, education, training, and 
degree of maturity or judgment obtained by the minor...the conduct and demeanor of the minor at the time of the incident involved...[and] the totality of the circumstances" in addition to the standard treatment competence factors. ${ }^{57}$ It is unclear how an evaluator, whether a health care professional or a judge, should assess maturity when it is defined by such an extraordinarily broad and open-ended list of factors. ${ }^{58}$ The concept of maturity as a precondition for independent health care decisionmaking by minors has existed in abortion law for decades. ${ }^{6}$ Yet there is no consensus about the meaning of the standard. In fact, the inherent malleability of the term "maturity" has allowed it to encompass the personal biases and preferences of judges regarding access to abortion for minors. ${ }^{52,59}$ Indeed, the broader and vaguer the test of maturity, the greater the likelihood that it will serve a as a repository for unstated values of clinical evaluators or presiding judges. A narrower and more specific standard of maturity that can be more easily operationalized is more likely to provide a meaningful yardstick for determining minors' decisional capacities. Yet application of focused criterion-relevant competence standards still requires those tasked with evaluating minors' treatment decision-making competence under applicable law to consider the developmental science related to psychosocial maturity discussed above. In particular, one should assess whether the circumstances that facilitate the operation of cold cognition are present. In any health care decision-making setting, factors that impair minors' abilities to exercise their logical reasoning and analytic processes should be identified and minimized to the extent possible.

\section{CONCLUSIONS}

Decisions about whether to allow an older minor to refuse medically recommended lifesaving intervention present some of the most challenging and emotionally wrenching dilemmas in law, bioethics, and clinical practice. In general, the law imposes a bright line between minority and majority for the purpose of authority to make such health care decisions. Yet occasionally such refusals fall within an existing legal exception, such as a mature minor rule. In other instances, adults authorized to decide under the law may, working in partnership with (or in opposition to) the treatment team, support a child's decision.

Although competent adults are permitted to refuse their own medical treatment for any reason, including for reasons that others would consider unwise, no such deference is granted in American law regarding health care decisions for minors. The decisions of both parents and minors (when the latter are permitted some decision-making authority) are subject to legal scrutiny based on the policy goals discussed in this article. When adjudicating cases in which legally authorized decision-makers refuse lifesaving treatment of minors, courts consider factors such as the relative balance of treatment burdens and benefits and the patients' prognosis with and without treatment. The state's interests in mandating treatment over the objections of parents or a mature minor diminish as the benefits of intervention become more elusive or less certain or as the burdens of the proposed treatment increase.

The Supreme Court of Delaware demonstrated the importance of such assessments in the case of Newmark $v$ Williams. $^{26}$ In that case, Colin

Newmark suffered from Burkitt lymphoma, described by the court as an "aggressive and advanced form of pediatric cancer." ${ }^{26}$ The only therapeutic option available to Colin offered a $40 \%$ chance of temporary remission, was described as radical, and itself posed serious risks to the child's survival. In light of the substantial treatment burdens and uncertain benefits, the judge declined to order treatment over parental objections. The case illustrates that, just as parental discretion is not absolute, neither is the state's pursuit of health interventions to safeguard a child's life.

On the basis of my review of published court decisions, the ruling in the case of Dennis Lindberg is an outlier. In light of a " $70 \%$ chance of disease-free survival,"11 ${ }^{11}$ gether with the conventional nature of the proposed treatment, most courts would have ordered treatment over the objections of Dennis and his legal guardian. Although Colin Newmark was a young child whose competence was not at issue, the case offers an important contrast. If Dennis Lindberg's medical prognosis with treatment had been poorer, if the risks of treatment had been greater, or if there had been greater uncertainty as to these factors, Dennis' (and his guardian's) interests in refusing treatment would have been weightier in the standard legal analysis. Furthermore, Dennis was several years away from the cusp of adulthood, a point at which some lawmakers sometimes find it more difficult to sustain the bright-line age demarcation of adulthood. ${ }^{29}$ Despite interjurisdictional variability, this case stands apart from others with similar fact patterns in vesting decisional autonomy in a younger adolescent whose prospects for a healthy future with conventional treatment were so bright.

\section{REFERENCES}

1. Grisso T, Vierling L. Minors' consent to treatment: a developmental perspective. Prof Psychol. 1978;9(3): 412-427

2. Melton GB, Koocher GP, Saks MJ, eds. Children's Competence to Consent. New York, NY: Plenum Press; 1983

3. Rodham H. Children under the law. Harv Educ Rev. 1973;43(4):487-514 
4. Parham v J.R., 442 US 584 (1979)

5. Carey v Population Services International, 431 US 678 (1977)

6. Bellotti v Baird, 443 US 622 (1979)

7. Melton GB. Toward "personhood" for adolescents. Autonomy and privacy as values in public policy. Am Psychol. 1983;38(1):99-103

8. Meisel A, Roth LH, Lidz CW. Toward a model of the legal doctrine of informed consent. Am J Psychiatry. 1977;134(3):285-289

9. Weithorn LA. Psychological distress, mental disorder, and assessment of decisionmaking capacity under U.S. medical aid in dying statutes. Hastings Law J. 2020;71(3):637-698

10. Weithorn LA, Reiss DR. Providing adolescents with independent and confidential access to childhood vaccines: a proposal to lower the age of consent. Conn Law Rev. 2020;52(2)

11. Diekema DS. Adolescent refusal of lifesaving treatment: are we asking the right questions? Adolesc Med State Art Rev. 2011;22(2):213-228, viii

12. Raftery I. When A 14-year-old chooses to die because of religion, can anyone stop him? 2015. Available at: http:// archive.kuow.org/post/when-14-yearold-chooses-die-because-religion-cananyone-stop-him. Accessed July 1, 2020

13. Committee on Bioethics. Informed consent in decision-making in pediatric practice. Pediatrics. 2016;138(2): e20161484

14. Katz AL, Webb SA; Committee on Bioethics. Informed consent in decisionmaking in pediatric practice. Pediatrics 2016;138(2):e20161485

15. Weithorn LA. Involving Children in Decisions Affecting Their Own Welfare: Guidelines for Professionals. In: Melton GB, Koocher GP, Saks MJ, eds. Children's Competence to Consent. New York, NY: Plenum Press; 1983:235-260

16. Troxel v Granville, 530 US 57 (2000)

17. Scott ES, Scott RE. From contract to status: collaboration and the evolution of novel family relationships. Columbia Law Rev. 2015;115:293-374

18. Weithorn LA. A constitutional jurisprudence of children's vulnerability. Hastings Law J. 2017;69: 179-274

19. Hill BJ. Medical decision making by and on behalf of adolescents reconsidering first principles. J Health Care Law Policy. 2012;15(1):37-73

20. Rosato JL. Let's get real: quilting a principled approach to adolescent empowerment in health care decisionmaking. De Paul Law Rev. 2002;51(3): 769-803

21. Goldstein J, Freud A, Solnit AJ. Before the Best Interests of the Child. New York, NY: Free Press; 1979

22. Beh HG, Diamond M. David Reimer's legacy: limiting parental discretion. Cardozo Journal of Law \& Gender. 2005; 12:5-30

23. Ehrlich JS. Shifting boundaries: abortion, criminal culpability and the indeterminate legal status of adolescents. Wis Womens Law J. 2003; 18(1):77-116

24. Reiss DR, Weithorn LA. Responding to the childhood vaccination crisis: legal frameworks and tools in the context of parental vaccine refusal. Buffalo Law Rev. 2015;63:881-980

25. Cal Welf \& Inst Code $\S 300(b)$ (1) (2019)

26. Newmark v Williams, 588 A2d 1008 (Del 1991)

27. In re Custody of a Minor, 379 NE2d 1053 (Mass 1978)

28. Centers for Disease Control and Prevention. Reproductive health: teen pregnancy. Available at: https://www. cdc.gov/teenpregnancy/about/index. htm. Accessed July 1, 2020

29. In Re E.G., 549 NE2d 322 (III 1989)

30. Grisso T, Appelbaum PS. Assessing Competence to Consent to Treatment: $A$ Guide for Physicians and Other Health Professionals. Oxford, United Kingdom: Oxford University Press; 1998

31. Appelbaum PS. Clinical practice. Assessment of patients' competence to consent to treatment. $N$ Engl J Med. 2007;357(18):1834-1840

32. Cal Prob Code $\S 4609$ (2019)

33. Gillick v West Norfolk and Wisbech Area Health Authority, AC 112 (House of Lords, United Kingdom 1986)

34. Cave E. Goodbye Gillick? Identifying and resolving problems with the concept of child competence. Leg Stud. 2014;34(1): 103-122

35. Weithorn LA. Developmental factors and competence to make informed treatment decisions. Child Youth Serv. 1982;5(1-2):85-100

36. Johnson SB, Blum RW, Giedd JN. Adolescent maturity and the brain: the promise and pitfalls of neuroscience research in adolescent health policy. J Adolesc Health. 2009;45(3):216-221

37. Steinberg L, Cauffman E, Woolard J, Graham S, Banich M. Are adolescents less mature than adults?: minors' access to abortion, the juvenile death penalty, and the alleged APA "flip-flop". Am Psychol. 2009;64(7):583-594

38. Icenogle G, Steinberg L, Duell N, et al. Adolescents' cognitive capacity reaches adult levels prior to their psychosocial maturity: evidence for a "maturity gap" in a multinational, cross-sectional sample. Law Hum Behav. 2019;43(1): 69-85

39. Steinberg L. Does recent research on adolescent brain development inform the mature minor doctrine? J Med Philos. 2013;38(3):256-267

40. Grootens-Wiegers $P$, Hein IM, van den Broek JM, de Vries MC. Medical decision-making in children and adolescents: developmental and neuroscientific aspects. BMC Pediatr. 2017;17(1):120

41. Expert Panel Working Group on MAID for Mature Minors. The state of knowledge on medical assistance in dying for mature minors. 2018. Available at: https://cca-reports.ca/wpcontent/uploads/2018/12/The-State-ofKnowledge-on-Medical-Assistance-inDying-for-Mature-Minors.pdf. Accessed July 1,2020

42. Miller VA, Drotar D, Kodish E. Children's competence for assent and consent: a review of empirical findings. Ethics Behav. 2004;14(3):255-295

43. Weithorn LA, Campbell SB. The competency of children and adolescents to make informed treatment decisions. Child Dev. 1982; 53(6):1589-1598

44. Hein IM, Troost PW, Lindeboom R, et al Accuracy of the MacArthur competence assessment tool for clinical research (MacCAT-CR) for measuring children's 
competence to consent to clinical research. JAMA Pediatr. 2014;168(12): 1147-1153

45. Hein IM, De Vries MC, Troost PW, Meynen G, Van Goudoever JB, Lindauer RJ. Informed consent instead of assent is appropriate in children from the age of twelve: policy implications of new findings on children's competence to consent to clinical research. BMC Med Ethics. 2015;16(1):76

46. Hein IM, Troost PW, Lindeboom R, et al. Feasibility of an assessment tool for children's competence to consent to predictive genetic testing: a pilot study. $J$ Genet Couns. 2015;24(6):971-977

47. Chenneville T, Machacek M, Tan R, LujanZilberman J, Emmanuel P, Rodriguez C. Decisional capacity among youth with HIV: results from the MacArthur competence tool for treatment. AIDS

Patient Care STDS. 2014;28(8):425-432

48. Schachter D, Tharmalingam S, Kleinman I. Informed consent and stimulant medication: adolescents' and parents' ability to understand information about benefits and risks of stimulant medication for the treatment of attention-deficit/hyperactivity disorder. J Child Adolesc Psychopharmacol. 2011;21(2):139-148

49. Wadlington W. Minors and health care: the age of consent. Osgoode Hall Law J. 1973;11(1):115-125

50. Holder AR. Legal Issues in Pediatrics and Adolescent Medicine, 2nd ed. New Haven, CT: Yale University Press; 1985

51. Coleman DL, Rosoff PM. The legal authority of mature minors to consent to general medical treatment. Pediatrics. 2013;131(4):786-793

52. Scott ES. The legal construction of adolescence. Hofstra Law Rev. 2000; 29(2):547-598

53. Benston S. Not of minor consequence? medical decision-making autonomy and the mature minor doctrine. Indiana Health Law Rev. 2016;13(1):1-16

54. Ark Code §20-9-602(7) (2019)

55. Idaho Code $\S 39-4508$ (2019)

56. In Re Swan, 569 A2d 1202 (Me 1990)

57. Cardwell v Bechtol, 724 SW2d 739, 748 (Tenn 1987)

58. Belcher v Charleston Area Medical Center, 422 SE2d 827 (W Va 1992)

59. Oberman M. Minor rights and wrongs. J Law Med Ethics. 1996;24(2):127-138 


\section{When Does A Minor's Legal Competence To Make Health Care Decisions Matter? \\ Lois A. Weithorn \\ Pediatrics 2020;146;S25 \\ DOI: $10.1542 /$ peds.2020-0818G}

$\begin{array}{ll}\begin{array}{l}\text { Updated Information \& } \\ \text { Services }\end{array} & \begin{array}{l}\text { including high resolution figures, can be found at: } \\ \text { http://pediatrics.aappublications.org/content/146/Supplement_1/S25 }\end{array} \\ \text { References } & \text { This article cites } 35 \text { articles, } 3 \text { of which you can access for free at: } \\ & \text { http://pediatrics.aappublications.org/content/146/Supplement_1/S25\# } \\ & \text { BIBL } \\ \text { Subspecialty Collections } & \text { This article, along with others on similar topics, appears in the } \\ & \text { following collection(s): } \\ & \text { Health Information Technology } \\ \text { http://www.aappublications.org/cgi/collection/health_information_te } \\ \text { chnology_sub } \\ \text { Telehealth Care } \\ \text { http://www.aappublications.org/cgi/collection/telehealth_care_sub } \\ \text { Information about reproducing this article in parts (figures, tables) or } \\ \text { in its entirety can be found online at: } \\ \text { http://www.aappublications.org/site/misc/Permissions.xhtml } \\ \text { Information about ordering reprints can be found online: } \\ \text { hermissions \& Licensing } \\ \text { http://www.aappublications.org/site/misc/reprints.xhtml }\end{array}$

\section{American Academy of Pediatrics}

DEDICATED TO THE HEALTH OF ALL CHILDREN ${ }^{\circledR}$

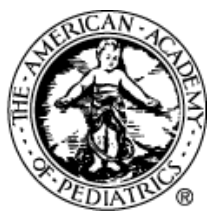




\title{
PE D I AT R I C S
}

OFFICIAL JOURNAL OF THE AMERICAN ACADEMY OF PEDIATRICS

\author{
When Does A Minor's Legal Competence To Make Health Care Decisions \\ Matter? \\ Lois A. Weithorn \\ Pediatrics 2020;146;:S25 \\ DOI: $10.1542 /$ peds.2020-0818G
}

The online version of this article, along with updated information and services, is located on the World Wide Web at:

http://pediatrics.aappublications.org/content/146/Supplement_1/S25

Pediatrics is the official journal of the American Academy of Pediatrics. A monthly publication, it has been published continuously since 1948. Pediatrics is owned, published, and trademarked by the American Academy of Pediatrics, 345 Park Avenue, Itasca, Illinois, 60143. Copyright (C 2020 by the American Academy of Pediatrics. All rights reserved. Print ISSN: 1073-0397.

\section{American Academy of Pediatrics}

DEDICATED TO THE HEALTH OF ALL CHILDREN ${ }^{\circledR}$ 